\title{
Can Corporate Governance Mitigate the Adverse Impact of Investor Sentiment on Corporate Investment Decisions? Evidence from Taiwan
}

\author{
Wei-Ju Chen \\ Department of Accounting \\ Tamkang University, Taiwan \\ Tel: (886-2)-26-215-656 Ext: 3365 E-mail: weiju@mail.tku.edu.tw
}

\begin{abstract}
Received: August 23, 2013 Accepted: September 25, 2013 Published: December 1, 2013
doi:10.5296/ajfa.v5i2.4117ＵRL: http://dx.doi.org/10.5296/ajfa.v5i2.4117
\end{abstract}

I gratefully acknowledge the financial support from National Science Council of Taiwan. The author thanks the anonymous referee for helpful comments. The author also thanks Ying-Ying Chu for help in collecting the data and Ju-Lan Tsai for research assistance.

\begin{abstract}
This paper explores whether investor sentiment has an adverse impact on corporate investment decisions and whether such impact, if present, can be effectively mitigated by sound corporate governance mechanisms. The sample comprises listed firms in Taiwan between 2003 and 2010. Empirical results indicate that investor sentiment is significantly and positively related to amount of new investment and over-investment. Investor sentiment has an adverse impact on corporate investment decisions. Further test for the moderating effect of corporate governance confirms that corporate governance mechanisms can mitigate such adverse impact of investor sentiment on corporate investment decisions. The empirical results support the argument of previous literature that corporate governance has both incentive and monitoring effects on managers' decision-making. Due to the agency problem, managers' investment decisions may be affected by investor sentiment and deviate from the goal of maximizing firm value. Therefore, firms should reinforce their corporate governance mechanisms to minimize the adverse impact of investor sentiment.
\end{abstract}

Keywords: Corporate Governance; Board of Director Mechanisms; Agency Theory; Investor Sentiment; Investment Decision 


\section{Introduction}

Classical financial theory assumes that investors are rational. The efficient market hypothesis suggests that share prices reflect all the information of a firm. However, recent studies show that investors are actually not rational and will be driven by emotional factors to make wrong investment decisions (e.g., Cornelli, Goldreich, \& Ljungqvist, 2006; De Long, Shleifer, Summers, \& Waldmann, 1990; Dorn, 2009; Shleifer \& Vishny, 1997). The presence of sentimental investors makes a firm's share price deviate from its fundamentals. In other words, a firm's share price is determined by not only its fundamentals but also investor sentiment. It has been documented in many studies that investor sentiment also has an impact on manager decisions (Baker, Stein, \& Wurgler, 2003; Baker \& Wurgler, 2004; Dong, Hirshleifer, \& Teoh, 2007; Gilchrist, Himmelberg, \& Huberman, 2005; Polk \& Sapienza, 2009). Therefore, this paper will explore whether investor sentiment has an adverse impact on corporate investment decisions and further examine whether such impact, if present, can be mitigated by sound corporate governance mechanisms.

Making investment decisions is an important activity in firm management. For sustainable operations, firms need to constantly expand and innovate their facilities and products. Investment decisions concern the allocation and use of resources and funds, usually in a large amount. A wrong decision can pose a serious threat to the survival of the firm. Hence, careful assessment of investment decisions is of high importance to firms. However, recent studies (e.g., Baker et al., 2003; Dong et al., 2007) have found that managers do not always make investment decisions in the interest of shareholders. The empirical finding in Baker et al. (2003) shows that the irrational element of stock prices may affect corporate investment through an equity financing channel. Through this equity financing channel, mispricing caused by investor sentiment has a positive effect on investment level, particularly among highly equity-dependent firms. In addition to the equity financing channel, investor sentiment can also affect investment decisions through a catering channel (Grundy \& Li, 2010; Kau, Linck, \& Rubin, 2008; Morck, Shleifer, Vishny, Shapiro, \& Poterba, 1990; Polk \& Sapienza, 2009). Managers may increase firm investment to cater to the optimistic (pessimistic) sentiment of investors (McConnell \& Muscarella, 1985). In doing so, they can achieve a quick boost of the firm's stock price and earn higher salary or compensation for themselves.

Managers operate the firm for firm owners. Hired by the firm, they are supposed to pursue maximum interest of shareholders. However, due to the agency problem, some managers may shirk or act in their own best interests (Jensen \& Meckling, 1976). No matter through which channel investor sentiment motivate managers to make decisions that lead to over-investment or under-investment, such decisions are detrimental to firm value. Previous research has obtained abundant evidence that sound corporate governance mechanisms can mitigate the agency problem and further increase firm performance and shareholder wealth (e.g., Agrawal \& Knoeber, 1996; Core, Guay, \& Rusticus, 2006; Cremers \& Nair, 2005). Based on this perspective, this paper will examine whether corporate governance mechanisms can induce or force managers to act toward maximization of firm value regardless of investor sentiment.

The main contributions of this paper are as follows: First, many studies have shown that 
mispricing caused by investor sentiment affects managers' investment decisions. This paper further examines whether corporate governance can moderate the relation between investor sentiment and investment decisions. Second, previous research of the impact of investor sentiment on investment decisions uses investment level as the main dependent variable. This paper employs the over-investment (under-investment) model introduced by Richardson (2006) to estimate the amount of over-investment and test whether investor sentiment has an adverse impact on investment decisions. Third, based on Baker \& Wurgler's (2006) methodology, this paper develops a composite index of investor sentiment through principal component analysis. Four proxy variables, including stock turnover, number of IPOs, consumer confidence index (CCI), and discretionary accruals are considered in the analysis. This composite index can better represent investor sentiment as it contains not only the market-wide and firm-level investor sentiment index but also the direct and indirect investor sentiment index. Fourth, due to the diversity and interchangeability of corporate governance mechanisms (Bathala \& Rao, 1995), the quality of a firm's corporate governance cannot be judged simply by the effectiveness of a single mechanism. This paper follows the method used by Bushman, Chen, Engel, and Smith (2004) and Young and Wu (2009) to integrate various corporate governance variables into a composite index of corporate governance. With this index, this paper further examines whether corporate governance mechanisms can mitigate the adverse impact of investor sentiment on investment decisions.

Our empirical results indicate that investor sentiment has an impact on corporate investment level. Firms tend to invest more when investors are more optimistic. Investment decisions that fluctuate with investor sentiment will result in abnormal firm investment. Managers are likely to over-invest when they increase their firm's investment under the influence of investor sentiment (no matter through the equity financing channel or through the catering channel). Excessive investment of resources into projects with little benefit for the firm will cause a persisting decline of firm value. As to the moderating effect of corporate governance, empirical evidence shows that increase of investment level and over-investment induced by the optimism of investors can be mitigated in the presence of effective corporate governance mechanisms. In other words, sound corporate governance mechanisms can offer positive incentives and constraints to managers to avoid the agency problem.

\section{Theoretical Background and Hypotheses}

\subsection{Investor Sentiment and Investment Decisions}

Investor sentiment affects stock prices, causing a deviation of stock prices from fundamentals (Baker \& Wurgler, 2006, 2007; Baker, Wurgler, \& Yuan, 2012; Lemmon \& Portniaguina, 2006; Shleifer \& Vishny, 1997). When investors are optimistic, they may overlook negative information and overreact to positive information, resulting in overvaluation of stock prices. Conversely, when investors are pessimistic, they may overlook positive information and overreact to negative information, resulting in undervaluation of stock prices. Investor sentiment causes mispricing, which in turn affects a firm's investment level through two main channels, namely the equity financing channel and the catering channel.

Keynes (1936) argues that stock prices contain an important element of irrationality. This 
element influences a firm's financing decisions and further investment decisions. Many studies have studied the equity financing channel through which managers' investment decisions are affected (Blanchard, Rhee, \& Summers, 1993; Bosworth, Hymans, \& Modigliani, 1975; Fischer \& Merton, 1984; Morck et al., 1990; Stein, 1996). Stein (1996), for instance, proposes a model of equity financing channel in which mispricing of a firm's stock causes changes in the financing conditions for the firm. The cost of equity financing for the firm is lower when its stock is overpriced. According to the market timing theory, managers will issue stocks to get finance. They increase the firm's investment after gaining sufficient finance for investment. If they invest without careful assessment, they may waste resources on projects with a negative net present value (NPV), which is a phenomenon called over-investment. If the firm's stock price is under-estimated, the cost of equity financing will be higher for the firm. In this case, managers will not issue stocks. They may reduce their firm's investment and even drop projects with a positive NPV, which is a phenomenon called under-investment. Therefore, mispricing is positively related to investment level and over-investment. This relation is particularly evident among highly equity-dependent firms. Baker et al. (2003) use empirical data to test Stein's (1996) model. Their findings reveal that investment level is positively related to the element of irrationality, and this relation is especially strong among highly equity-dependent firms. Based on Baker et al.'s (2003) research design, Chang, Tam, Tan, and Wong (2007) draw upon a large panel of Australian firms to investigate if mispricing caused by investor sentiment has an impact on investment level. Their finding supports that investor sentiment affects corporate investment through the equity financing channel. Dong et al. (2007) also find that capital expenditure and research and development expenditure increase with mispricing among overvalued firms.

The equity financing channel hypothesis states that investor sentiment affects firm investment through the market timing for equity offerings. The effect of investor sentiment on firm investment is indirect. According to this hypothesis, firms with a huge amount of internal funds or a high debt capacity do not need to obtain finance for investment from the equity market. In other words, their investment decisions are not susceptible to fluctuation of stock prices. In addition to the equity financing channel, many studies have found that investor sentiment also affects firm investment through the catering channel (Grundy \& Li, 2010; Kau et al., 2008; Morck et al., 1990; Polk \& Sapienza, 2009). They state that mispricing affects investment decisions when managers have an incentive to cater to the optimistic (or pessimistic) sentiment of investors, even in the absence of high equity dependence. Due to information asymmetry, potential investors value a firm based on their observation of the firm's investment behavior (Chan, Martin, \& Kensinger, 1990; Chung, Wright, \& Charoenwong, 1998; McConnell \& Muscarella, 1985; Trueman, 1986). According to the catering theory, when investors are optimistic but managers refuse to invest in projects favored by the investors, the investors may sell their shares, causing a slump of the firm's stock price. Therefore, managers will choose to increase (decrease) investment to cater to the optimistic (pessimistic) sentiment of investors to maximize the firm's share price in a short time and earn higher salary or compensation for themselves. However, over-investment and under-investment are likely to occur when managers overly cater to investor sentiment. Polk and Sapienza (2009) use discretionary accruals as a proxy for mispricing caused by investor 
sentiment to test if corporate investment caters to investor sentiment. Their empirical finding suggests a significant and positive relation between corporate investment and discretionary accruals. Grundy and Li (2010) also empirically confirm that managers seeking to maximize short-term shareholder value may increase corporate investment that caters to investor sentiment. Besides, if there is a high level of investor optimism, a higher share of ownership may provide managers with an incentive to over-invest. Based on the above theories and discussions, this paper proposes the following hypotheses:

\section{Hypothesis 1: A higher level of investor optimism leads to more new investment.}

Hypothesis 2: A higher level of investor optimism leads to more over-investment.

\subsection{Investor Sentiment, Corporate Governance Mechanisms, and Investment Decisions}

Jensen and Meckling (1976) propose the agency theory, suggesting that due to separation of ownership and management, managers may put aside the interest of shareholders while seeking their own interest. Investment expenditure is an important corporate decision and usually involves a huge amount of money. However, the agency problem may occur when managers make investment decisions that do not best serve the interest of shareholders but their own interest. Jensen (1986) puts forth the "over-investment” problem, a problem that occurs when managers do not seek maximization of shareholder wealth but personal interests, such as social reputation, higher reward or more compensation, through continuous firm expansion. If the free cash flow is large, managers are also more likely to invest in negative NPV projects. Such investment, called over-investment, will further decrease the firm's value and harm the interest of shareholders.

The incentives and monitoring mechanisms of corporate governance can mitigate the agency problem. Theoretically, corporate governance has a positive effect on firm value and the quality of managerial decision-making. However, the extant empirical research has mixed conclusions about the impact of corporate governance on the quality of managers' investment decisions. The finding of Masulis, Wang, and Xie (2007) suggests that firms with better corporate governance are more efficient in acquisition. Huang, Huang, and Chang (2011) point out that corporate governance offer monitoring mechanisms which can ensure that managers make better investment decisions and avoid the over-investment problem. Both Harford, Mansi, and Maxwell (2008) and Richardson (2006) reveal that firms with poor corporate governance tend to have greater industry-adjusted investment. Bertrand and Mullainathan (2003) and Giroud and Mueller (2010) find that poor corporate governance results in under-investment. However, Richardson (2006) argues that only a small portion of corporate governance mechanisms can effectively mitigate over-investment.

Mispricing caused by investor sentiment can cause an increase in firm investment or even over-investment through the equity financing channel or the catering channel. According to the agency theory, sound corporate governance mechanisms offer incentives and monitoring effects that can lead and force managers to make decisions in pursuit of higher firm value. Assume that investors have a high degree of optimism, and managers obtain a large cash flow due to market timing. Firms with better corporate governance mechanisms may be able to 
motivate and compel their managers to make proper investment decisions and avoid over-investment in negative NPV projects. Moreover, they can also motivate and compel their managers not to over-invest only to cater to investor sentiment. Based on the above discussions, this paper proposes the following hypotheses:

Hypothesis 3: In the presence of better corporate governance mechanisms, the effect of investor sentiment on new investment is smaller.

Hypothesis 4: In the presence of better corporate governance mechanisms, the effect of investor sentiment on over-investment (under-investment) is smaller.

\section{Data and Methodology}

\subsection{Data and Sample Selection}

This paper draws on a sample comprising publicly listed firms in Taiwan from 2003 to 2010. Firms in the financial industry and firms with missing variables are excluded from the sample. The final sample includes 7745 firm-year observations. The values of Consumer Confidence Index (CCI) are obtained from the monthly survey conducted by The Research Center for Taiwan Economic Development, National Central University. The data of other variables of investor sentiment, corporate governance, and investment decision (including basic firm data, stock price, stock trading volume, IPO data, ownership structure, board composition, and financial reports) are obtained from Taiwan Economic Journal (TEJ).

\subsection{Empirical Model}

The proposed hypotheses are tested using the following regression models. In Equation (1), the independent variable is investor sentiment (SENTI), and the dependent variable is new investment (INVEST). This equation is intended to examine the relation between investor sentiment and new investment level. In Equation (2), the independent variable is investor sentiment (SENTI), and the dependent variable is over-investment (under-investment) (OVERINVEST). This equation examines the relation between investor sentiment and over-investment. Both Equation (3) and Equation (4) contain an interaction term of investor sentiment and corporate governance $\left(S E N T I^{*} C G I\right)$ to test the relation of investor sentiment to investment level and over-investment under different levels of corporate governance. The selection and measurement of each variable is explained as follows. The operational definition of all the variables is provided in Table 1.

$$
\begin{aligned}
& I_{N V E S T} i_{i, t}=\beta_{0}+\beta_{1} S_{E N T I} I_{i, t}+\beta_{2} C F_{i, t}+\beta_{3} Q_{i, t-1}+\beta_{4} S I Z E_{i, t}+\varepsilon_{i, t} \\
& \text { OVERINVEST }_{i, t}=\beta_{0}+\beta_{1} \operatorname{SENTI}_{i, t}+\beta_{2} C F_{i, t}+\beta_{3} Q_{i, t-1}+\beta_{4} \operatorname{SIZE}_{i, t}+\varepsilon_{i, t} \\
& \operatorname{INVEST}_{i, t}=\beta_{0}+\beta_{1} \operatorname{SENTI}_{i, t}+\beta_{2} \operatorname{CGI}_{i, t}+\beta_{3} \operatorname{SENTI}_{i, t} * C G I_{i, t}+\beta_{4} C F_{i, t} \\
& +\beta_{5} Q_{i, t-1}+\beta_{6} S I Z E_{i, t}+\varepsilon_{i, t} \\
& \text { OVERINVEST }_{i, t}=\beta_{0}+\beta_{1} \text { SENTI }_{i, t}+\beta_{2} C_{G I_{i, t}}+\beta_{3} \operatorname{SENTI}_{i, t} * C G I_{i, t}+\beta_{4} C F_{i, t} \\
& +\beta_{5} Q_{i, t-1}+\beta_{6} S I Z E_{i, t}+\varepsilon_{i, t}
\end{aligned}
$$




\subsection{Variables Definitions and Measurement}

\subsubsection{Investment Variables}

In this paper, the dependent variables include new investment (INVEST) and over-investment (OVERINVEST). According to Richardson (2006) and Strong and Meyer (1990), total investment expenditure is the sum of all outlays on capital expenditure, acquisitions, and research and development less receipts from the sale of property, plant, and equipment. Total investment expenditure can be broken down into required investment expenditure to maintain assets in place (for which amortization and depreciation can be used as the proxy) and investment expenditure on new projects. Hence, new investment (INVEST) is total investment expenditure minus amortization and depreciation expense. To estimate the amount of over-investment, this paper employs the method introduced by Richardson (2006). The expected level of new investment is estimated using Equation (5). The fitted value from the regression is the estimate of the expected level of new investment. And the residual from the regression is the estimate of over-investment. The residual can be negative or positive. Positive (negative) values denote over-investment (under-investment).

$$
\begin{aligned}
\text { INVEST }_{i, t}=\beta_{0} & +\beta_{1} \text { GROWTH }_{i, t-1}+\beta_{2} \text { LEVERAGE }_{i, t-1}+\beta_{3} \text { CASH }_{i, t-1} \\
& +\beta_{4} \operatorname{Ln}_{(\text {AGE })_{i, t-1}+\beta_{5} \operatorname{Ln}(\operatorname{SIZE})_{i, t-1}+\beta_{6} \text { STOCK RETRUN }_{i, t-1}+\beta_{7} \text { INVEST }_{i, t-1}} \\
& +\sum \text { Year Indicator }+\sum \text { Industry Indicator }+\varepsilon_{i, t}
\end{aligned}
$$

\subsubsection{Investor Sentiment Variables}

To examine whether an individual firm's investment decisions are affected by investor sentiment, we need to capture firm-specific investor sentiment. Based on the methodology of previous research (e.g., Baker \& Wurgler, 2006; Polk \& Sapienza, 2009), this paper uses individual stock turnover (TURN) and discretionary accruals (DACCR) as proxies of investor sentiment at the firm level. In addition, number of IPOs (NIPO) and Consumer Confidence Index $(C C I)$ are used as proxies for investor sentiment at the market level. Each investor sentiment proxy is likely to include a sentiment component as well as some idiosyncratic, non-sentiment-related components. Following Baker and Wurgler (2006), this paper performs principal component analysis to isolate the common components. The development of each proxy variable for investor sentiment and how we build a composite index of investor sentiment (SENTI) is explained as follows.

In this paper, we use four proxy variables of investor sentiment, including TURN, DACCR, $N I P O$, and CCI. First of all, we estimate the first principal component of the four proxies and their lags. This gives us a first-stage index with eight loadings, one for each of the current and lagged proxies. We then compute the correlation between the first-stage index and the current and lagged values of each of the proxies. Finally, we define SENTI as the first principal component of the correlation matrix of four variables-each respective proxy's lead or lag, whichever has the higher correlation with the first-stage index. This procedure produces a composite index of investor sentiment as follows. The first principal component explains $43.94 \%$ of the sample variance. 
SENTI $_{t}=0.7057$ NIPO $_{t-1}+0.0674$ DACCR $_{t-1}+0.0400$ TURN $_{t-1}+0.7041$ CCI $_{t-1}$

Stock Turnover (TURN). Baker and Stein (2004) indicate that turnover can serve as a proxy for investor sentiment. When irrational investors are optimistic, they participate in the market and thus increase the turnover. Following this idea, Baker and Wurgler (2006) include the market turnover variable in their composite sentiment index to test the relationship between investor sentiment and the cross-section of stock returns. In this paper, we use stock turnover as a proxy for the sentiment of irrational investors. High turnover denotes that investors are optimistic about the firm, and low turnover denotes that investors are pessimistic about the firm.

Discretionary Accruals (DACCR). The optimism of investors causes overpricing of a stock. Sloan (1996) and Teoh, Welch, and Wong (1998) find that firms with higher discretionary accruals have lower abnormal returns in the long run and therefore infer that the current stock prices of these firms are overpriced. Chi and Gupta (2009) and Polk and Sapienza (2009) also use discretionary accruals as a proxy for sentiment-induced mispricing. Based on these studies, we also view discretionary accruals as one of the proxies for investor sentiment. High (low) discretionary accruals indicate the current stock prices are overpriced (underpriced) and investors are optimistic (pessimistic). We estimate discretionary accruals using the method introduced by Polk and Sapienza (2009).

Number of IPOs (NIPO). The IPO market is often viewed as sensitive to investor sentiment. According to the market timing theory, managers offer IPOs when stock trading is highly active and their stock prices are overpriced (Baker \& Wurgler, 2002; Lucas \& McDonald, 1990). It can be inferred that investors are more optimistic when the number of IPOs is greater.

Consumer Confidence Index (CCI). The Research Center for Taiwan Economic Development, National Central University, surveys consumer confidence index $(C C I)$ on a monthly basis. Unlike the other three indices which evaluate investment sentiment based on indirect data, CCI directly measures the degree to which investors are optimistic about the future. CCI is a direct index of investor sentiment. We use this index as a proxy for investor sentiment. CCI considers six factors, including consumers' confidence for investment in the next six months, timing of buying durables, household economic conditions, domestic price level, domestic employment opportunities, and the economic climate. The values of this index fall between 0 200. Values above 100 denote investors are optimistic, and values below 100 denote investors are pessimistic. Higher CCI indicates higher investor optimism (Qiu \& Welch, 2004).

\subsubsection{Corporate Governance Variables}

Bathala and Rao (1995) point out that many mechanisms of corporate governance can be substituted for one another, so a firm's corporate governance cannot be measured by the effectiveness of only one of the mechanisms. In order to take into account a wider spectrum of variables of corporate governance, we adopt the method used by Bushman et al. (2004), Cheng, Gul, Tong, and Tsui (2008), and Young and Wu (2009). This method is to combine 
various corporate governance variables into one composite variable to assess the quality of corporate governance. We first select four variables related to board composition to measure the monitoring effects of corporate governance, including the efficiency and independence of monitoring. In addition, we select three variables concerning ownership structure to measure the incentive effects of corporate governance, including the incentive for board monitoring and the incentive for the controlling shareholder to reduce expropriation. Finally, we combine these seven variables into one composite corporate governance index (CGI). The variables in each of the two constructs are explained as follows:

Board Composition. Four variables of board composition are considered, including board size (BODSIZE), chairman duality (DUALITY), ratio of outside directors (OUTBOD), and presence of independent directors or supervisors (IND). Jensen (1993) and Yermack (1996) have noted that when the board size is too large, incongruence of opinions and conflict of interest are likely to occur and further slash the effectiveness of board monitoring. We sort all the total numbers of directors on the board in descending order and compute the percentile of each value. At last, each percentile is converted into a BODSIZE value between $0 \sim 1$. In Taiwan, $76 \%$ of listed firms are family firms, and $66.45 \%$ are fully controlled by the largest family shareholder (Yeh, 1999). Because family members hold decisive shares, agency problem is likely to occur between controlling shareholders and minority shareholders in family firms. If the director of the board is simultaneously served by a family member or the ultimate controller, the independence and monitoring effect of the board may be compromised. The board can better supervise the manager without chairman duality. Therefore, we set DUALITY as a dummy variable. The value is 1 if the chairman is not served by a family member or the ultimate controller; the value is 0 if otherwise.

Fama (1980), Firstenberg and Malkiel (1980), and Weisbach (1988) have mentioned that a higher ratio of outside directors on the board increases the supervisory power of the board and is positive for firm value. Beasley (1996) finds a negative relation between increase in the number of outside directors and occurrence of financial statement error and fraud. This finding suggests that the presence of more outside directors can help increase the reliability of accounting information. In this paper, we calculate the ratio of outside directors in each firm and sort all the values into ascending order, so that we can convert each of them into a percentile value of OUTBOD between $0 \sim 1$. Sivaramakrishnan and Yu (2008) indicate that firms with more independent directors have better corporate governance. We set the presence of independent directors (IND) as a dummy variable, which is coded 1 if independent directors or supervisors are present on the board and 0 if otherwise. Finally, we sum the values of the four variables, namely BODSIZE, DUALITY, OUTBOD, and IND to form a composite board composition index (CG-BOD). The value of this variable ranges between 0 and 4. Higher values indicate higher effectiveness of the board.

Ownership Structure. Three variables of ownership structure are considered, including ratio of shares held by board members (BSHOLD), deviation of control rights and cash flow rights $(D E V)$, and equity pledge ratio of directors and supervisors (PLEDGE). Dechow, Sloan, and Sweeney (1996) and Jensen and Meckling (1976) suggest that when directors or supervisors hold a high ratio of shares of the firm, they will be more motivated by a high correlation 
between their financial risk and the firm's performance to monitor the management. In this paper, we sort all the ratios of board ownership in ascending order to compute the percentile for each firm, so that the value can be further converted into a BSHOLD value between $0 \sim 1$. Deviation of control rights and cash flow rights $(D E V)$ is the difference between control rights and cash flow rights of the ultimate controller. It can be used to measure the quality of a firm's corporate governance (Claessens, Djankov, \& Lang, 2000; La Porta, Lopez-de-Silanes, Shleifer, \& Vishny, 2002). If DEV is large, controlling shareholders can control the firm with a small cash flow and there may be a stronger incentive for them to embezzle the firm's assets and expropriate minority shareholders. Therefore, a larger $D E V$ leads to worse corporate governance. We sort all the values of difference between control rights and cash flow rights in descending order and compute their percentiles, so that each value can be transformed into a $D E V$ value between $0 \sim 1$. Values closer to 1 indicate better corporate governance.

According to Kao, Chiou, and Chen (2004) and Yeh, Lee, and Woidtke (2001), a higher equity pledge ratio of the board suggests that directors and supervisors are highly involved in the stock market and have collateralized their holdings in exchange for cash. There will be a smaller incentive for the directors and supervisors to manage the firm properly, and ethical crisis is likely to occur. Therefore, higher pledge results in worse corporate governance. We sort all the pledge ratios in descending order and compute the percentile of each ratio to obtain a PLEDGE value between $0 \sim 1$ for each firm. Values closer to 1 indicate better corporate governance. We sum the values of BSHOLD, DEV, and PLEDGE to get a composite ownership structure index $(C G-O W N)$. The values will range between $0 \sim 3$, and the greater the value, the better the corporate governance. Finally, we add up the board composition index (CG-BOD) and the ownership structure index (CG-OWN) to form a composite corporate governance index (CGI). This index ranges from 0 to 7 . This index denotes the strength of corporate governance mechanisms, so the higher the index, the better the corporate governance.

\subsubsection{Control Variables}

The control variables in this study include cash flow (CF), investment opportunity $(Q)$, and firm size (SIZE). Both Grundy and Li (2010) and Richardson (2006) have found a positive relation between cash holdings and investment expenditure. Hence, cash flow should be controlled. Besides, firms tend to invest more when they can have more investment opportunities. Most previous studies use Tobin's Q as a proxy for investment opportunity (Chen, Ho, Lee, \& Yeo, 2000; Polk \& Sapienza, 2009; Richardson, 2006). Tobin’s Q is the ratio between the market value and replacement value of the total assets. As replacement value of firm assets is not accessible, we use the book value of firm assets instead (Chung \& Pruitt, 1994). Finally, firm size is controlled, and the total assets at the beginning of the year is used as a proxy for firm size. 
Table 1. Variables Description

\begin{tabular}{|c|c|c|}
\hline Variable & Symbol & Variable Description and Definition \\
\hline \multicolumn{3}{|c|}{ Variables in the primary model: } \\
\hline New investment & INVEST & $\begin{array}{l}\text { The sum of all outlays on capital expenditure, acquisitions } \\
\text { and research and development less receipts from the sale } \\
\text { of property, plant and equipment minus amortization and } \\
\text { depreciation expense }\end{array}$ \\
\hline Over investment & OVERINVEST & The residual from regression (5) \\
\hline Sentiment indexes & SENTI & $\begin{array}{l}\text { The first principal component of the correlation matrix of } \\
T U R N_{t-1}, D A C C R_{t-1}, C C I_{t-1} \text { and } N I P O_{t-1} \text {. }\end{array}$ \\
\hline $\begin{array}{l}\text { Corporate governance } \\
\text { composite indexes }\end{array}$ & CGI & $\begin{array}{l}\text { The sum of BODSIZE, DUALITY, OUTBOD, IND, } \\
\text { BSHOLD, DEV and PLEDGE. }\end{array}$ \\
\hline Cash flow & $C F$ & $\begin{array}{l}\text { The sum of income before extraordinary items and } \\
\text { depreciation and amortization }\end{array}$ \\
\hline Tobin’s Q & $Q$ & $\begin{array}{l}\text { The market value of total assets deflated by the book } \\
\text { value of total assets }\end{array}$ \\
\hline Firm size & SIZE & Total assets measured at the start of the year. \\
\hline
\end{tabular}

Variables in the over-investment model:
Growth
GROWTH

Leverage

LEVERAGE

Cash CASH

$\begin{array}{ll}\text { Firm age } & \operatorname{Ln}(\text { AGE }) \\ \text { Firm size } & \operatorname{Ln}(\text { SIZE }) \\ \text { Stock return } & \text { STOCK RETURN }\end{array}$

Investor Sentiment Variables

Turnover ratios

TURN

Discretionary accruals

DACCR
Change of prime operating revenue divided by prime operating revenue at the beginning

The sum of the book value of short term and long term debt deflated by the sum of the book value of total debt and the book value of equity.

The balance of cash and short term investments deflated by total assets.

Logarithm of the number of years since incorporation.

Logarithm of total assets.

The market-adjusted stock returns.

The ratio of trading volume to outstanding shares of the firm.

$\operatorname{DACCR}_{i, t}=$ ACCR $_{i, t}-$ NORMALACCR $_{i, t}$

$\mathrm{ACCR}_{\mathrm{i}, \mathrm{t}}=\Delta \mathrm{NCCA}_{\mathrm{i}, \mathrm{t}}-\Delta \mathrm{CL}_{\mathrm{i}, \mathrm{t}}-\mathrm{DEP}_{\mathrm{i}, \mathrm{t}}$

NORMALACCR $_{\mathrm{i}, \mathrm{t}}=\frac{\sum_{\mathrm{k}=1}^{5} \operatorname{ACCR}_{\mathrm{i}, \mathrm{t}-\mathrm{k}}}{\sum_{\mathrm{k}=1}^{5} \operatorname{SALES}_{\mathrm{i}, \mathrm{t}-\mathrm{k}}}$ ALES $_{\mathrm{i}, \mathrm{t}}$

Where:

$\triangle$ NCCA is the change in noncash current assets.

$\triangle \mathrm{CL}$ is the change in current liabilities minus the change in debt included in current liabilities and minus the change in income taxes payable. 
Table 1. Variables Description (Continued)

\begin{tabular}{|c|c|c|}
\hline Variable & Symbol & Variable Description and Definition \\
\hline $\begin{array}{l}\text { Consumer Confidence } \\
\text { Index }\end{array}$ & CCI & $\begin{array}{l}\text { DEP is depreciation and amortization expense. } \\
\text { SALES is net sales of firms. } \\
\text { CCI is calculated based on the survey results provided by } \\
\text { the Research Center for Taiwan Economic Development, } \\
\text { National Central University. }\end{array}$ \\
\hline The number of IPOs & NIPO & The number of IPOs in year t. \\
\hline \multicolumn{3}{|c|}{ Corporate Governance Variables } \\
\hline Board size & BODSIZE & $\begin{array}{l}\text { All the total numbers of directors on the board are sorted } \\
\text { in descending order before computing the percentiles. } \\
\text { Each percentile is converted into a value between } 0 \sim 1 \text {. }\end{array}$ \\
\hline Chairman internalization & DUALITY & $\begin{array}{l}\text { A dummy variable which is coded one if the chairman is } \\
\text { not served by the ultimate controller or a family member } \\
\text { and zero if otherwise. }\end{array}$ \\
\hline $\begin{array}{l}\text { The percentage of } \\
\text { outside directors }\end{array}$ & OUTBOD & $\begin{array}{l}\text { All the ratios of outside directors are sorted in ascending } \\
\text { order before computing the percentiles. Each percentile is } \\
\text { converted into a value between } 0 \sim 1 \text {. }\end{array}$ \\
\hline $\begin{array}{l}\text { Presence of independent } \\
\text { directors or supervisors }\end{array}$ & IND & $\begin{array}{l}\text { A dummy variable which is coded one if the board has } \\
\text { independent director(s) or supervisor(s) and zero if } \\
\text { otherwise. }\end{array}$ \\
\hline $\begin{array}{l}\text { The composite board } \\
\text { composition index }\end{array}$ & $C G-B O D$ & The sum of BODSIZE, DUALITY, OUTBOD and IND. \\
\hline Board ownership ratio & BSHOLD & $\begin{array}{l}\text { All the ratios of shares held by board members to shares } \\
\text { outstanding are sorted in ascending order before } \\
\text { computing the percentiles. Each percentile is converted } \\
\text { into a value between } 0 \sim 1 \text {. }\end{array}$ \\
\hline $\begin{array}{l}\text { The deviation of control } \\
\text { rights and cash flow } \\
\text { rights }\end{array}$ & $D E V$ & $\begin{array}{l}\text { All the differences between control rights and cash flow } \\
\text { rights of the ultimate controller are sorted in descending } \\
\text { order before computing the percentiles. Each percentile is } \\
\text { converted into a value between } 0 \sim 1 \text {. }\end{array}$ \\
\hline $\begin{array}{l}\text { Equity pledge ratio of } \\
\text { the board }\end{array}$ & PLEDGE & $\begin{array}{l}\text { All the pledge ratios are sorted in descending order before } \\
\text { computing the percentiles. Each percentile is converted } \\
\text { into a value between } 0 \sim 1 \text {. }\end{array}$ \\
\hline $\begin{array}{l}\text { The composite } \\
\text { ownership structure } \\
\text { index }\end{array}$ & $C G-O W N$ & The sum of $B S H O L D, D E V$ and $P L E D G E$. \\
\hline
\end{tabular}

This table provides description and definition of the variables. 


\section{Empirical Results and Analysis}

\subsection{Descriptive Statistics}

The descriptive statistics for the main variables are presented in Table 2. Panel A shows the average new investment is $\mathbf{\$ 6 3 6}$ million, and the abnormal investment ranges between \$-151,749 million $\$ 368,091$ million. Panel B shows the data of proxies for investor sentiment. The mean turnover (TURN) is $211.44 \%$, and the mean value of discretionary accruals (DACCR) is \$-67.13 million. The difference between the minimum and the maximum of each variable is large, suggesting that investor sentiment varies greatly from firm to firm. At the market level, CCI values fall between 54.49 78.53, and the number of IPOs (NIPO) ranges between 34.00 124.00. The principal component analysis shows that the mean of the composite investor sentiment index (SENTI) is 0, with a standard deviation of 1.33. Overall, $C C I$ values fall between $0 \sim 100$, and the mean value of discretionary accruals is negative, suggesting that investors are slightly pessimistic during the sample period.

Panel C presents the data of variables of corporate governance. The mean composite board composition index (CG_BOD) is 1.69 (on a scale of 0 to 4). Among the elements of this index, the mean board size (BODSIZE) is 6.83, the mean DUALITY is 0.19 , meaning only $19 \%$ of the firms do not have the chairman duality problem. In other words, most sample firms are run by a manager who is also the controlling shareholder or a family member of the controlling shareholder and likely to have the agency problem. The mean ratio of outside directors is $34 \%$, which is not high. Besides, $43 \%$ of the firms have independent directors and supervisors. The mean composite ownership structure index (CG_OWN) is 1.66 (on a scale of 0 to 3 ). Among the elements of this index, the mean ownership ratio (BSHOLD) and pledge ratio (PLEDGE) of board members are $23.38 \%$ and $9.48 \%$ respectively. The maximum deviation of control rights and cash flow rights $(D E V)$ reaches as high as $90.62 \%$. The sum of the composite board composition index $\left(C G \_B O D\right)$ and the composite ownership structure index (CG_OWN) is the composite corporate governance index (CGI). The theoretical range of this value is between $0 \sim 7$. The worse firm in the sample has 0.41 on this index, and the best has 6.64 .

\subsection{Investor Sentiment and New Investment}

Table 3 examines how investor sentiment is related to new investment with sentiment indexes as independent variables, new investment as dependent variable, and cash flow, investment opportunity, and firm size as control variables. The data employed in this research are panel data. As shown in Equation (1) (4), we conduct OLS with year dummies controlled, fixed effect regression with and without time effect, and random effect regression respectively to increase the robustness of the results. Empirical results indicate that sentiment indexes are positively related to new investment at $1 \%$ significance level. Therefore, Hypothesis 1 is supported. That is, higher optimism of investors leads to more new investment. Due to the consideration of equity financing cost or the incentive to cater to investor sentiment (Baker et al., 2003; Polk \& Sapienza, 2009), managers may increase their firm's new investment when investors are optimistic about their firm. Among the control variables, cash flow $(C F)$ is significantly and positive related to new investment in the fixed effect regression model. 
Tobin's Q is also significantly and positively related to new investment. As mentioned earlier, managers invest more to increase firm value when they spot good investment opportunities for the firm. Total assets and new investment are significantly and positively related. New investment also increases relatively with firm size.

Table 2. Descriptive Statistics

\begin{tabular}{|c|c|c|c|c|c|}
\hline & Mean & Std. Dev. & Minimum & Median & Maximum \\
\hline \multicolumn{6}{|c|}{ Panel A: Investment variables and control variables } \\
\hline INVEST (million) & 636 & 6,948 & $-111,834$ & 52 & 381,619 \\
\hline OVERINVEST (million) & 0 & 6,643 & $-151,749$ & -139 & 368,091 \\
\hline CF (million) & 1,730 & 9,041 & $-26,494$ & 211 & 229,476 \\
\hline SIZE (million) & 17,799 & 585,940 & 32 & 3,827 & $1,380,532$ \\
\hline Q & 0.73 & 0.74 & -0.63 & 0.55 & 11.82 \\
\hline \multicolumn{6}{|c|}{ Panel B: Investor sentiment variables } \\
\hline TURN (\%) & 211.44 & 194.17 & 0.07 & 154.57 & 1581.29 \\
\hline DACCR (million) & -67.13 & 3,116.94 & $-94,772.25$ & -10.35 & $41,446.21$ \\
\hline CCI & 68.04 & 8.48 & 54.49 & 68.75 & 78.53 \\
\hline NIPO (Number of IPO firms) & 62.96 & 28.82 & 34.00 & 52.00 & 124.00 \\
\hline SENTI & 0.00 & 1.33 & -3.57 & -0.41 & 2.51 \\
\hline \multicolumn{6}{|c|}{ Panel C: Corporate governance variables } \\
\hline CG_BOD & 1.69 & 0.79 & 0.00 & 1.80 & 3.95 \\
\hline $\begin{array}{l}\text { BODSIZE (Number of } \\
\text { seats) }\end{array}$ & 6.83 & 2.33 & 2.00 & 7.00 & 27.00 \\
\hline BODSIZE (0-1) & 0.62 & 0.30 & 0.00 & 0.56 & 1.00 \\
\hline DUALITY & 0.19 & 0.39 & 0.00 & 0.00 & 1.00 \\
\hline OUTBOD (\%) & 34.08 & 21.23 & 0.00 & 37.50 & 100.00 \\
\hline OUTBOD (0-1) & 0.45 & 0.29 & 0.00 & 0.47 & 1.00 \\
\hline IND & 0.43 & 0.50 & 0.00 & 0.00 & 1.00 \\
\hline CG_OWN & 1.66 & 0.60 & 0.18 & 1.72 & 2.99 \\
\hline BSHOLD (\%) & 23.38 & 13.83 & 0.00 & 19.97 & 94.95 \\
\hline BSHOLD (0-1) & 0.45 & 0.28 & 0.00 & 0.42 & 1.00 \\
\hline DEV (\%) & 5.29 & 9.31 & 0.00 & 1.31 & 90.62 \\
\hline $\operatorname{DEV}(0-1)$ & 0.54 & 0.32 & 0.00 & 0.52 & 1.00 \\
\hline PLEDGE (\%) & 9.48 & 18.16 & 0.00 & 0.00 & 100.00 \\
\hline PLEDGE (0-1) & 0.68 & 0.41 & 0.00 & 1.00 & 1.00 \\
\hline CGI & 3.35 & 1.07 & 0.41 & 3.39 & 6.64 \\
\hline
\end{tabular}

This table presents summary statistics for the dependent and independent variables. Variable description is specified in Table 1. 
Table 3. Investor Sentiment and New Investment

\begin{tabular}{lcccc}
\hline & $(1)$ & $(2)$ & $(3)$ & $(4)$ \\
\cline { 2 - 5 } & OLS & \multicolumn{2}{c}{ Fixed Effects } & Random Effects \\
\hline SENTI & $2870.72^{* * *}$ & $303.97^{* * *}$ & $4328.99^{* * *}$ & $237.05^{* * *}$ \\
& $(3.09)$ & $(5.96)$ & $(4.80)$ & $(4.81)$ \\
$\mathrm{CF}_{\mathrm{t}}$ & 0.02 & $0.04^{*}$ & 0.02 & 0.00 \\
& $(1.50)$ & $(1.78)$ & $(0.93)$ & $(0.15)$ \\
$\mathrm{Q}_{\mathrm{t}-1}$ & $233.90^{* * *}$ & $455.24^{* * *}$ & $350.03^{* *}$ & $366.39^{* * *}$ \\
& $(2.37)$ & $(3.32)$ & $(2.34)$ & $(3.09)$ \\
SIZE $_{\mathrm{t}}$ & $0.05^{* * *}$ & $0.08^{* * *}$ & $0.08^{* * *}$ & $0.07^{* * *}$ \\
& $(23.07)$ & $(20.90)$ & $(21.09)$ & $(22.65)$ \\
INTERCEPT & $-6,644.27^{* * *}$ & $-1,172.87^{* * *}$ & $-10,009.71^{* * *}$ & $-702.89^{* * *}$ \\
Year dummies & $(-3.35)$ & $(-8.89)$ & $(-5.21)$ & $(-3.73)$ \\
\hline$N$ & Yes & No & Yes & \\
$\mathrm{R}^{2}$ & 7,745 & 7,745 & 7,745 & 7,745 \\
\hline
\end{tabular}

The table examines how investor sentiment is related to new investment. The dependent variable is new investment (INVEST). The independent variables include sentiment index $\left(S E N T I_{t}\right)$, cash flow $\left(C F_{\mathrm{t}}\right)$, Tobin's $\left.\mathrm{Q}\left(\mathrm{Q}_{\mathrm{t}-1}\right)\right)$ and firm size $\left(S I Z E_{\mathrm{t}}\right)$. Detailed definitions of the variables are given in Table 1. T-statistics (for OLS and fixed effects models) or Z-statistics (for random effects model) are reported below the estimated coefficients. The symbols ***, $* *$, and * denote statistical significance at 1 percent, 5 percent, and 10 percent levels respectively.

\subsection{Investor Sentiment and Over-Investment}

Table 4 examines the relation between investor sentiment and over-investment through four models, including OLS with year dummies controlled, fixed effect regressions with and without time effect, and random effect regression. The empirical findings indicate that the higher the sentiment index, the larger the over-investment. For instance, in the fixed effect model with time effect, an increase of sentiment index by 1 causes an increase in over-investment by $\$ 7,537$ million. If investors are overly optimistic, managers may increase firm investment due to market timing or an incentive to cater to investor sentiment. The increased investment is likely to become over-investment. Conversely, if investors are overly pessimistic, under-investment is likely to occur. The results offer support for Hypothesis 2, that is, higher investor optimism leads to more over-investment. Among the control variables, Tobin's Q is significantly and positively related to abnormal investment in some models, implying that over-investment is more likely to occur when there are more investment opportunities. Besides, firm size is positively related to over-investment. 
Table 4. Investor Sentiment and Over-Investment

\begin{tabular}{lcccc}
\hline & $(1)$ & $(2)$ & $(3)$ & $(4)$ \\
\hline SENTI $_{\mathrm{t}}$ & OLS & \multicolumn{2}{c}{ Fixed Effects } & Random Effects \\
& $4,114.26^{* * *}$ & $231.68^{* * *}$ & $7,537.18^{* * *}$ & $153.44^{* * *}$ \\
$\mathrm{CF}_{\mathrm{t}}$ & $(4.34)$ & $(4.35)$ & $(8.02)$ & $(2.99)$ \\
& 0.02 & 0.01 & -0.02 & -0.02 \\
$\mathrm{Q}_{\mathrm{t}-1}$ & $(1.43)$ & $(0.50)$ & $(-0.98)$ & $(-0.90)$ \\
& -2.34 & $293.71^{* *}$ & $274.96^{*}$ & 170.03 \\
SIZE $_{\mathrm{t}}$ & $(-0.02)$ & $(2.05)$ & $(1.76)$ & $(1.39)$ \\
& $0.03^{* * *}$ & $0.06^{* * *}$ & $0.07^{* * *}$ & $0.05^{* * *}$ \\
INTERCEPT & $(12.76)$ & $(16.26)$ & $(17.17)$ & $(16.12)$ \\
& $-9,167.71^{* * *}$ & $-1,376.87^{* * *}$ & $-16,811.22^{* * *}$ & $-830.12^{* * *}$ \\
Year dummies & $(-4.53)$ & $(-9.99)$ & $(-8.39)$ & $(-4.44)$ \\
\hline$N$ & Yes & No & Yes & \\
$\mathrm{R}^{2}$ & 7,745 & 7,745 & 7,745 & 7,745 \\
\hline
\end{tabular}

The table examines how investor sentiment is related to over-investment. The dependent variable is over-investment (OVERINVEST). The independent variables include sentiment index $\left(S E N T I_{t}\right)$, cash flow $\left(C F_{\mathrm{t}}\right)$, Tobin's $\left.\mathrm{Q}\left(\mathrm{Q}_{\mathrm{t}-1}\right)\right)$ and firm size $\left(S I Z E_{\mathrm{t}}\right)$. Detailed definitions of the variables are given in Table 1. T-statistics (for OLS and fixed effects models) or Z-statistics (for random effects model) are reported below the estimated coefficients. The symbols $* * *, * *$, and $*$ denote statistical significance at 1 percent, 5 percent, and 10 percent levels respectively.

\subsection{Investor Sentiment, Corporate Governance, and Investment Decisions}

In order to examine whether corporate governance can mitigate the impact of investor sentiment on investment decisions, we include the interaction term between corporate governance indexes and sentiment indexes in the regression equations. Table 5 shows whether board composition moderates the relationship between investor sentiment and investment decisions. The empirical results of Equation (1)-(4) indicate that the interaction term between board composition (CG_BOD) and investor sentiment (SENTI) is significantly and negatively related to new investment (INVEST). In other words, the higher the board composition index, the less that investor sentiment will positively affect new investment. Firms with a better board structure can more effectively monitor managers' decision-making and reduce the adverse impact of investor sentiment on their investment decisions. On the other hand, the results of Model (5)-(8) indicate that the interaction term between board composition (CG_BOD) and investor sentiment (SENTI) is also significantly and negatively related to over-investment (OVERINVEST). In other words, if there is a high level of investor optimism, the better the board composition, the more effectively that the board can monitor managers and prevent them from over-investing only to cater to investor sentiment or because of the availability of free cash flow. The board plays a central role in corporate governance. 
The board is responsible for monitoring managerial performance, preventing conflict of interests, and ensuring compliance of firm operations with various laws. If the board has a better composition, it can exert its monitoring function more independently and efficiently. As a result, the impact of investor sentiment that causes inefficient allocation of resources and harms the interest of shareholders can be effectively mitigated.

Table 6 includes the interaction term between ownership structure (CG_OWN) and sentiment indexes (SENTI) to examine whether ownership structure moderates the relationship between investor sentiment and investment decisions. The results of Equation (1) (4) indicate that the interaction term of CG_OWN and SENTI is significantly and negatively related to new investment (INVEST). The results of Equation (5) (8) indicate that the interaction term of CG_OWN and SENTI is also significantly and negatively related to over-investment (OVERINVEST). In other words, better ownership structure can mitigate the impact of investor sentiment on new investment and over-investment. The ownership structure index $\left(C G \_O W N\right)$ measures the incentive effects of corporate governance mechanisms. Higher board ownership ratios indicate a higher alignment of board interest to shareholder interest, and there is a stronger incentive for the board to monitor managerial decisions. A high pledge ratio of the board means that board members have collateralized most of their shares in exchange for cash. Thus, there is a weak incentive for them to monitor managerial decisions. Besides, equity collateralization will deepen the connection between the personal finance of board members and the firm's stock price, offering an incentive for board members to encourage firm investment that results in a stock price increase. Finally, higher deviation between control rights and cash flow rights (DEV) offer an incentive for the controlling shareholder to expropriate minority investors. Such incentive can be reduced if $D E V$ is low. Therefore, the quality of ownership structure concerns the incentives for monitoring and expropriation. Our empirical evidence confirms that the better the ownership structure, the more effectively that managers' investment decisions can be monitored, and the smaller the incentive for expropriation will be. Better ownership structure can help mitigate the adverse impact of investor sentiment on investment that concerns the long-term value of the firm.

Finally, based on the board structure index (CG_BOD) and the ownership structure index (CG_OWN), we analyze whether the overall quality of corporate governance (CGI) can moderate the relation between investor sentiment and investment decisions. As shown in Table 7, the interaction term between SENTI and CGI is significantly and negatively related to both new investment (INVEST) and over-investment (OVERINVEST). In other words, the higher the composite corporate governance index (CGI), the more that the impact of investor sentiment on new investment and over-investment can be mitigated. The results in Table 5 7 supports Hypothesis 3 and Hypothesis 4, which assert that better corporate governance mechanisms can mitigate the impact of investor sentiment on new investment and over-investment (under-investment) respectively. To sum up, investor sentiment influences a firm's investment level, even to the extent of over-investment or under-investment; the effect of investor sentiment can be mitigated if better corporate governance mechanisms are present. 
Table 5. Investor Sentiment and Investment Decisions - The Moderating Effect of Board Composition

\begin{tabular}{|c|c|c|c|c|c|c|c|c|}
\hline & (1) & $(2)$ & (3) & (4) & (5) & $(6)$ & $(7)$ & (8) \\
\hline & \multicolumn{4}{|c|}{ Dependent variable $=$ INVEST } & \multicolumn{4}{|c|}{ Dependent variable $=$ OVERINVEST } \\
\hline & OLS & \multicolumn{2}{|c|}{ Fixed Effects } & \multirow{3}{*}{$\begin{array}{c}\text { Random Effects } \\
686.74^{* * *} \\
(5.95)\end{array}$} & \multirow{3}{*}{$\begin{array}{c}\text { OLS } \\
4,401.99^{* * *} \\
(4.63)\end{array}$} & \multicolumn{2}{|c|}{ Fixed Effects } & \multirow{3}{*}{$\begin{array}{c}\text { Random Effect } \\
629.64^{* * *} \\
(5.24)\end{array}$} \\
\hline SENTI $_{t}$ & $3,166.65^{* * *}$ & $710.12^{* * *}$ & $4,579.49^{* * *}$ & & & $667.62^{* * *}$ & $7,781.53^{* * *}$ & \\
\hline & (3.40) & (5.94) & (5.06) & & & $(5.35)$ & $(8.25)$ & \\
\hline \multirow[t]{2}{*}{ CG_BOD ${ }_{\mathrm{t}}$} & $276.44^{* * *}$ & -298.07 & -317.08 & 223.90 & $375.42^{* * *}$ & -283.19 & -234.85 & $303.96^{* *}$ \\
\hline & $(2.95)$ & $(-1.51)$ & $(-1.60)$ & $(1.53)$ & (3.93) & $(-1.37)$ & $(-1.14)$ & (2.05) \\
\hline \multirow[t]{2}{*}{$\mathrm{CG}_{-} \mathrm{BOD}_{\mathrm{t}} * \mathrm{SENTI}_{\mathrm{t}}$} & $-275.91^{* * *}$ & $-260.76^{* * *}$ & $-281.50^{* * *}$ & $-283.46^{* * *}$ & $-269.38^{* * *}$ & $-279.92^{* * *}$ & $-264.02^{* * *}$ & $-298.45^{* * *}$ \\
\hline & $(-3.91)$ & $(-3.75)$ & $(-3.99)$ & $(-4.27)$ & $(-3.74)$ & $(-3.86)$ & $(-3.59)$ & $(-4.32)$ \\
\hline \multirow[t]{2}{*}{$\mathrm{CF}_{\mathrm{t}}$} & 0.02 & $0.04^{*}$ & 0.02 & 0.00 & 0.01 & 0.01 & -0.02 & -0.02 \\
\hline & $(1.24)$ & $(1.78)$ & $(0.96)$ & $(0.01)$ & $(1.09)$ & $(0.50)$ & $(-0.96)$ & $(-1.06)$ \\
\hline \multirow[t]{2}{*}{$\mathrm{Q}_{\mathrm{t}-1}$} & $184.50^{*}$ & $474.14^{* * *}$ & $372.10^{* *}$ & $361.63^{* * *}$ & -66.44 & $314.07^{* *}$ & $295.76^{*}$ & 158.48 \\
\hline & (1.85) & (3.46) & (2.49) & (3.05) & $(-0.65)$ & (2.19) & (1.90) & (1.30) \\
\hline \multirow[t]{2}{*}{$\operatorname{SIZE}_{\mathrm{t}}$} & $0.05^{* * *}$ & $0.08^{* * * *}$ & $0.08^{* * *}$ & $0.07^{* * *}$ & $0.03^{* * *}$ & $0.07^{* * *}$ & $0.07^{* * * *}$ & $0.05^{* * *}$ \\
\hline & (23.27) & $(21.25)$ & (21.45) & (22.93) & (13.19) & (16.63) & (17.47) & (16.44) \\
\hline \multirow[t]{2}{*}{ INTERCEPT } & $-6,834 \cdot 13^{* * *}$ & $-754.07^{* *}$ & $-9,300.54^{* * *}$ & $-1,174.27^{* * *}$ & $-9,486.07^{* * *}$ & $-988.45^{* * *}$ & $-16,265.97^{* * * *}$ & $-1,440.42^{* * *}$ \\
\hline & $(-3.44)$ & $(-2.12)$ & $(-4.75)$ & $(-3.70)$ & $(-4.68)$ & $(-2.66)$ & $(-7.98)$ & $(-4.52)$ \\
\hline Year dummies & Yes & No & Yes & & Yes & No & Yes & \\
\hline $\mathrm{N}$ & 7,745 & 7,745 & 7,745 & 7,745 & 7,745 & 7,745 & 7,745 & 7,745 \\
\hline $\mathrm{R}^{2}$ & 0.18 & 0.09 & 0.10 & & 0.07 & 0.05 & 0.06 & \\
\hline
\end{tabular}

This table examines whether board composition moderates the effect of investor sentiment on new investment and over-investment. The independent variables include sentiment indexes $\left(S E N T I_{t}\right)$, board composition indexes $\left(C G_{-} B O D_{t}\right)$, cash flow $\left(C F_{t}\right)$, Tobin's $Q\left(Q_{\mathrm{t}-1}\right)$, firm size $\left(S I Z E_{\mathrm{t}}\right)$ and the interaction term of board composition indexes and sentiment indexes $\left(C G_{-} B O D_{t} * S E N T I_{t}\right)$. Detailed definitions of the variables are given in Table 1. T-statistics (for OLS and fixed effects models) or Z-statistics (for random effects model) are reported below the estimated coefficients. The symbols $* * *, * *$, and * denote statistical significance at 1 percent, 5 percent, and 10 percent levels respectively. 
Table 6. Investor Sentiment and Investment Decisions - The Moderating Effect of Ownership Structure

2013, Vol. 5, No. 2

\begin{tabular}{|c|c|c|c|c|c|c|c|c|}
\hline & $(1)$ & $(2)$ & (3) & (4) & (5) & $(6)$ & (7) & $(8)$ \\
\hline & \multicolumn{4}{|c|}{ Dependent variable =INVEST } & \multicolumn{4}{|c|}{ Dependent variable =OVERINVEST } \\
\hline & OLS & \multicolumn{2}{|c|}{ Fixed Effects } & Random & OLS & \multicolumn{2}{|c|}{ Fixed Effects } & Random \\
\hline SENTI $_{t}$ & $\begin{array}{c}3,256.86^{* * *} \\
(3.47)\end{array}$ & $\begin{array}{c}1,229.41^{* * *} \\
(8.06)\end{array}$ & $\begin{array}{c}4,764.68^{* * *} \\
(5.28)\end{array}$ & $\begin{array}{c}972.77^{* * *} \\
(6.58)\end{array}$ & $\begin{array}{c}4,840.38^{* * *} \\
\quad(5.06)\end{array}$ & $\begin{array}{c}1,113.92^{* * *} \\
(6.99)\end{array}$ & $\begin{array}{c}7,930.40^{* * *} \\
(8.43)\end{array}$ & $\begin{array}{c}824.72^{* * *} \\
(5.36)\end{array}$ \\
\hline CG_OWN & $\begin{array}{c}245.84^{* *} \\
(2.00)\end{array}$ & $\begin{array}{r}213.56 \\
(0.93)\end{array}$ & $\begin{array}{r}208.82 \\
(0.91)\end{array}$ & $\begin{array}{r}229.05 \\
(1.25)\end{array}$ & $\begin{array}{c}681.13^{* * *} \\
(5.44)\end{array}$ & $\begin{array}{r}390.95 \\
(1.63)\end{array}$ & $\begin{array}{r}395.48^{*} \\
(1.65)\end{array}$ & $\begin{array}{c}522.44^{* * *} \\
(2.79)\end{array}$ \\
\hline $\mathrm{CG}_{-} \mathrm{OWN}_{\mathrm{t}} * \mathrm{SENTI}_{\mathrm{t}}$ & $\begin{array}{c}-194.26^{* *} \\
(-2.15)\end{array}$ & $\begin{array}{c}-563.27^{* * *} \\
(-6.44)\end{array}$ & $\begin{array}{c}-538.62^{* * *} \\
(-6.15)\end{array}$ & $\begin{array}{c}-448.26^{* * *} \\
(-5.29)\end{array}$ & $\begin{array}{r}-155.54^{*} \\
(-1.69)\end{array}$ & $\begin{array}{c}-537.80^{* * *} \\
(-5.89)\end{array}$ & $\begin{array}{c}-482.45^{* * *} \\
(-5.28)\end{array}$ & $\begin{array}{c}-409.35^{* * *} \\
(-4.64)\end{array}$ \\
\hline $\mathrm{CF}_{\mathrm{t}}$ & $\begin{array}{c}0.02 \\
(1.35)\end{array}$ & $\begin{array}{c}0.04^{*} \\
(1.67)\end{array}$ & $\begin{array}{c}0.02 \\
(0.92)\end{array}$ & $\begin{array}{c}0.00 \\
(0.00)\end{array}$ & $\begin{array}{c}0.01 \\
(0.96)\end{array}$ & $\begin{array}{c}0.01 \\
(0.39)\end{array}$ & $\begin{array}{c}-0.02 \\
(-1.00)\end{array}$ & $\begin{array}{c}-0.02 \\
(-1.07)\end{array}$ \\
\hline $\mathrm{Q}_{\mathrm{t}-1}$ & $\begin{array}{r}235.73^{* *} \\
(2.39)\end{array}$ & $\begin{array}{c}437.51^{* * *} \\
(3.20)\end{array}$ & $\begin{array}{c}339.48^{* *} \\
(2.28)\end{array}$ & $\begin{array}{c}357.42^{* * *} \\
(3.02)\end{array}$ & $\begin{array}{l}-4.75 \\
(-0.05)\end{array}$ & $\begin{array}{r}273.91^{*} \\
(1.91)\end{array}$ & $\begin{array}{r}262.13^{*} \\
(1.69)\end{array}$ & $\begin{array}{r}158.84 \\
(1.31)\end{array}$ \\
\hline SIZE $_{\mathrm{t}}$ & $\begin{array}{c}0.05^{* * *} \\
(23.05)\end{array}$ & $\begin{array}{c}0.08^{* * *} \\
(21.50)\end{array}$ & $\begin{array}{c}0.08^{* * *} \\
(21.61)\end{array}$ & $\begin{array}{c}0.07^{* * *} \\
(22.99)\end{array}$ & $\begin{array}{c}0.03^{* * *} \\
(13.62)\end{array}$ & $\begin{array}{c}0.07^{* * *} \\
(16.86)\end{array}$ & $\begin{array}{c}0.07^{* * *} \\
(17.66)\end{array}$ & $\begin{array}{c}0.05^{* * *} \\
(16.61)\end{array}$ \\
\hline INTERCEPT & $\begin{array}{c}-7,207.59^{* * *} \\
(-3.54)\end{array}$ & $\begin{array}{c}-1,567.97^{* * *} \\
(-3.86)\end{array}$ & $\begin{array}{c}-9,466.07^{* * *} \\
(-4.83)\end{array}$ & $\begin{array}{c}-1,115.76^{* * *} \\
(-3.06)\end{array}$ & $\begin{array}{r}-11,300.38^{* * *} \\
(-5.46)\end{array}$ & $\begin{array}{c}-2,066.27^{* * *} \\
(-4.87)\end{array}$ & $\begin{array}{r}-16,679.46^{* * *} \\
(-8.16)\end{array}$ & $\begin{array}{c}-1,738.95^{* * *} \\
(-4.72)\end{array}$ \\
\hline Year dummies & Yes & No & Yes & & Yes & No & Yes & \\
\hline$N$ & 7,745 & 7,745 & 7,745 & 7,745 & 7,745 & 7,745 & 7,745 & 7,745 \\
\hline $\mathrm{R}^{2}$ & 0.18 & 0.09 & 0.10 & & 0.07 & 0.06 & 0.07 & \\
\hline
\end{tabular}

This table examines whether ownership structure moderates the effect of investor sentiment on new investment and over-investment. The independent variables include sentiment indexes $\left(S E N T I_{t}\right)$, ownership structure indexes $\left(C G-O W N_{t}\right)$, cash flow $\left(C F_{t}\right)$, Tobin's Q $\left(Q_{\mathrm{t}-1}\right)$, firm size $\left(S I Z E_{\mathrm{t}}\right)$ and the interaction term of ownership structure indexes and sentiment indexes $\left(C G-O W N_{t} * S E N T I_{t}\right)$. Detailed definitions of the variables are given in Table 1. T-statistics (for OLS and fixed effects models) or Z-statistics (for random effects model) are reported below the estimated coefficients. The symbols $* * *, * *$, and $*$ denote statistical significance at 1 percent, 5 percent, and 10 percent levels respectively. 
Table 7. Investor Sentiment and Investment Decisions -The Moderating Effect of Corporate Governance

\begin{tabular}{|c|c|c|c|c|c|c|c|c|}
\hline & $(1)$ & $(2)$ & (3) & (4) & (5) & (6) & (7) & $(8)$ \\
\hline & \multicolumn{4}{|c|}{ Dependent variable =INVEST } & \multicolumn{4}{|c|}{ Dependent variable =OVERINVEST } \\
\hline & OLS & \multicolumn{2}{|c|}{ Fixed Effects } & Random & OLS & \multicolumn{2}{|c|}{ Fixed Effects } & Random Effects \\
\hline \multirow[t]{2}{*}{ SENTI $_{t}$} & $3,498.15^{* * *}$ & $1,335.07^{* * *}$ & $4,931.71^{* * *}$ & $1,199.68^{* * *}$ & $4,879.97^{* * *}$ & $1,275.33^{* * *}$ & $8,112.15^{* * *}$ & $1,116.57^{* * *}$ \\
\hline & (3.74) & $(7.92)$ & $(5.45)$ & $(7.40)$ & $(5.12)$ & $(7.24)$ & $(8.60)$ & $(6.62)$ \\
\hline \multirow[t]{2}{*}{$\mathrm{CGI}_{\mathrm{t}}$} & $243.14^{* * *}$ & -13.57 & -28.39 & $236.80^{* *}$ & $436.97^{* * *}$ & 63.50 & 84.40 & $379.12^{* * *}$ \\
\hline & $(3.50)$ & $(-0.09)$ & $(-0.20)$ & $(2.18)$ & $(6.17)$ & $(0.42)$ & $(0.56)$ & $(3.44)$ \\
\hline \multirow[t]{2}{*}{$\mathrm{CGI}_{\mathrm{t}} * \mathrm{SENTI}_{\mathrm{t}}$} & $-212.33^{* * *}$ & $-321.98^{* * *}$ & $-326.08^{* * *}$ & $-298.01^{* * *}$ & $-199.00^{* * *}$ & $-326.10^{* * *}$ & $-301.22^{* * *}$ & $-296.74^{* * *}$ \\
\hline & $(-4.17)$ & $(-6.41)$ & $(-6.42)$ & $(-6.21)$ & $(-3.84)$ & $(-6.21)$ & $(-5.69)$ & $(-5.94)$ \\
\hline \multirow[t]{2}{*}{$\mathrm{CF}_{\mathrm{t}}$} & 0.02 & $0.04^{*}$ & 0.02 & -0.00 & 0.01 & 0.01 & -0.03 & -0.02 \\
\hline & $(1.12)$ & $(1.70)$ & $(0.93)$ & $(-0.09)$ & $(0.76)$ & $(0.40)$ & $(-1.00)$ & $(-1.19)$ \\
\hline \multirow[t]{2}{*}{$\mathrm{Q}_{\mathrm{t}-1}$} & $193.52^{*}$ & $471.18^{* * *}$ & $372.25^{* *}$ & $355.64^{* * *}$ & -73.29 & $308.82^{* *}$ & $293.86^{*}$ & 147.65 \\
\hline & (1.95) & (3.44) & $(2.50)$ & $(3.00)$ & $(-0.73)$ & $(2.16)$ & (1.89) & $(1.21)$ \\
\hline \multirow[t]{2}{*}{$\mathrm{SIZE}_{\mathrm{t}}$} & $0.05^{* * *}$ & $0.08^{* * *}$ & $0.08^{* * *}$ & $0.07^{* * *}$ & $0.03^{* * *}$ & $0.07^{* * *}$ & $0.07^{* * *}$ & $0.05^{* * *}$ \\
\hline & $(23.34)$ & $(21.60)$ & $(21.74)$ & (23.23) & (13.83) & (16.94) & (17.73) & (16.85) \\
\hline \multirow[t]{2}{*}{ INTERCEPT } & $-7,355.65^{* * *}$ & $-1,244.53^{* *}$ & $-9,244.85^{* * *}$ & $-1,622.35^{* * *}$ & $-10,824.03^{* * *}$ & $-1,706.78^{* * *}$ & $-16,505.24^{* * *}$ & $-2,233.97^{* * *}$ \\
\hline & $(-3.66)$ & $(-2.47)$ & $(-4.65)$ & $(-3.86)$ & $(-5.28)$ & $(-3.25)$ & $(-7.97)$ & $(-5.27)$ \\
\hline Year dummies & Yes & No & Yes & & Yes & No & Yes & \\
\hline $\mathrm{N}$ & 7,745 & 7,745 & 7,745 & 7,745 & 7,745 & 7,745 & 7,745 & 7,745 \\
\hline $\mathrm{R}^{2}$ & 0.18 & 0.09 & 0.10 & & 0.07 & 0.06 & 0.07 & \\
\hline
\end{tabular}

This table examines whether corporate governance mechanisms moderate the effect of investor sentiment on new investment and over-investment. The independent variables include sentiment indexes $\left(S E N T I_{t}\right)$, corporate governance composite indexes $\left(C G I_{t}\right)$, cash flow $\left(C F_{\mathrm{t}}\right)$, Tobin's $\mathrm{Q}\left(Q_{\mathrm{t}-1}\right)$, firm size $\left(S I Z E_{\mathrm{t}}\right)$ and the interaction term of corporate governance composite indexes and sentiment indexes $\left(C G I_{t}{ }^{*}\right.$ $S E N T I_{t}$ ). Detailed definitions of the variables are given in Table 1. T-statistics (for OLS and fixed effects models) or Z-statistics (for random effects model) are reported below the estimated coefficients. The symbols ***, **, and * denote statistical significance at 1 percent, 5 percent, and 10 percent levels respectively. 


\section{Conclusions}

The contemporary research of behavioral finance suggests that managerial decision-making is influenced by investor sentiment. The fluctuation of investor sentiment can affect a firm's investment levels through the equity financing channel or the catering channel. Investment decisions that are not made through careful assessment for optimal investment are disadvantageous to firm value and shareholder interest. The purpose of this paper is to investigate the impact of investor sentiment on investment decisions, including the amount of new investment and over-investment, and further examine whether corporate governance can mitigate this impact.

Empirical results show that higher investor optimism leads to more new investment and over-investment, supporting the argument that investor sentiment has an adverse impact on investment decisions. Previous research has documented that such adverse impact mainly stems from the agency problem. Generally, a manager's performance is evaluated primarily by the firm's stock price. Their concern of personal performance, salary or compensation may drive them to seek maximization of the firm's stock price within a short time (Grundy \& $\mathrm{Li}, 2010$ ). Therefore, when investors are optimistic, managers may make decisions that can cause a short-term boost of the firm's price to cater to investor sentiment. However, such decisions are likely to result in over-investment. On the other hand, when investors are optimistic, the cost of equity financing can be lower. Managers are likely to obtain more finance than needed. The excessive cash flow will reduce the efficiency of firm management and investment, causing over-investment (Harford, 1999; Jensen, 1986; Opler, Pinkowitz, Stulz, \& Williamson, 1999, 2001). All these problems can affect a firm's resource allocation and jeopardize the interest of the firm and shareholders.

Finally, the empirical evidence confirms that corporate governance can mitigate the adverse impact of investor sentiment on investment decisions. In the presence of sound corporate governance mechanisms, the impact of investor sentiment on new investment and over-investment is smaller. Sound corporate governance mechanisms can motivate board members to perform their monitoring function, reduce controlling shareholders' expropriation intention, and supervisor firm decisions effectively and independently. In the presence of sound corporate governance mechanisms, managers will be less likely to be motivated by self-interest to overly cater to investor sentiment or by market timing considerations to acquire too much cash flow that results in a waste of resources or over-investment. In order to increase firm value, firms should reinforce their corporate governance mechanisms, strengthen the monitoring function of the board, and improve the effectiveness of their ownership structure to inhibit self-serving or opportunistic behavior of managers and mitigate the adverse impact of investor sentiment on their investment decisions.

\section{References}

Agrawal, A., \& Knoeber, C. R. (1996). Firm performance and mechanisms to control agency problems between managers and shareholders. The Journal of Financial and Quantitative Analysis, 31(3), 377-397. http://dx.doi.org/10.2307/2331397 
Baker, M., \& Stein, J. C. (2004). Market liquidity as a sentiment indicator. Journal of Financial Markets, 7(3), 271-299. http://dx.doi.org/10.1016/j.finmar.2003.11.005

Baker, M., Stein, J. C., \& Wurgler, J. (2003). When does the market matter? Stock prices and the investment of equity-dependent firms. The Quarterly Journal of Economics, 118(3), 969-1005. http://dx.doi.org/10.1162/00335530360698478

Baker, M., \& Wurgler, J. (2002). Market timing and capital structure. The Journal of Finance, 57(1), 1-32. http://dx.doi.org/10.1111/1540-6261.00414

Baker, M., \& Wurgler, J. (2004). A catering theory of dividends. The Journal of Finance, 59(3), 1125-1165. http://dx.doi.org/10.1111/j.1540-6261.2004.00658.x

Baker, M., \& Wurgler, J. (2006). Investor sentiment and the cross-section of stock returns. The Journal of Finance, 61(4), 1645-1680. http://dx.doi.org/10.1111/j.1540-6261.2006.00885.x

Baker, M., \& Wurgler, J. (2007). Investor sentiment in the stock market. The Journal of Economic Perspectives, 21(2), 129-152. http://dx.doi.org/10.1257/jep.21.2.129

Baker, M., Wurgler, J., \& Yuan, Y. (2012). Global, local, and contagious investor sentiment. $\begin{array}{llll}\text { Journal of Financial 272-287. } & \text { Economics, }\end{array}$ http://dx.doi.org/10.1016/j.jfineco.2011.11.002

Bathala, C. T., \& Rao, R. P. (1995). The determinants of board composition: An agency theory perspective. Managerial and Decision Economics, 16(1), 59-69. http://dx.doi.org/10.1002/mde.4090160108

Beasley, M. S. (1996). An empirical analysis of the relation between the board of director composition and financial statement fraud. The Accounting Review, 71(4), 443-465.

Bertrand, M., \& Mullainathan, S. (2003). Enjoying the quiet life? Corporate governance and managerial preferences. Journal of Political Economy, 111(5), 1043-1075. http://dx.doi.org/10.1086/376950

Blanchard, O., Rhee, C., \& Summers, L. (1993). The stock market, profit, and investment. The Quarterly Journal of Economics, 108(1), 115-136. http://dx.doi.org/10.2307/2118497

Bosworth, B., Hymans, S., \& Modigliani, F. (1975). The stock market and the economy. Brookings Papers on Economic Activity, 1975(2), 257-300. http://dx.doi.org/10.2307/2534104

Bushman, R., Chen, Q., Engel, E., \& Smith, A. (2004). Financial accounting information, organizational complexity and corporate governance systems. Journal of Accounting and Economics, 37(2), 167-201. http://dx.doi.org/10.1016/j.jacceco.2003.09.005

Chan, S. H., Martin, J. D., \& Kensinger, J. W. (1990). Corporate research and development expenditures and share value. Journal of Financial Economics, 26(2), 255-276. http://dx.doi.org/10.1016/0304-405X(90)90005-K 
Chang, X., Tam, L. H. K., Tan, T. J., \& Wong, G. (2007). The real impact of stock market mispricing- Evidence from Australia. Pacific-Basin Finance Journal, 15(4), 388-408. http://dx.doi.org/10.1016/j.pacfin.2006.06.003

Chen, S. S., Ho, K. W., Lee, C. f., \& Yeo, G. H. H. (2000). Investment opportunities, free cash flow and market reaction to international joint ventures. Journal of Banking \& Finance, 24(11), 1747-1765. http://dx.doi.org/10.1016/S0378-4266(99)00103-X

Cheng, P., Gul, F. A., Tong, W. H. S., \& Tsui, J. (2008). Does corporate governance affect firm value? Evidence with corporate governance indices. Paper presented the AAA Conference.

Chi, J., \& Gupta, M. (2009). Overvaluation and earnings management. Journal of Banking \& Finance, 33(9), 1652-1663. http://dx.doi.org/10.1016/j.jbankfin.2009.03.014

Chung, K. H., \& Pruitt, S. W. (1994). A simple approximation of Tobin's Q. Financial Management, 23(3), 70. http://dx.doi.org/10.2307/3665623

Chung, K. H., Wright, P., \& Charoenwong, C. (1998). Investment opportunities and market reaction to capital expenditure decisions. Journal of Banking \& Finance, 22(1), 41-60. http://dx.doi.org/10.1016/S0378-4266(97)00021-6

Claessens, S., Djankov, S., \& Lang, L. H. P. (2000). The separation of ownership and control in East Asian corporations. Journal of Financial Economics, 58(1-2), 81-112. http://dx.doi.org/10.1016/S0304-405X(00)00067-2

Core, J. E., Guay, W. R., \& Rusticus, T. O. (2006). Does weak governance cause weak stock returns? An examination of firm operating performance and investors' expectations. The Journal of Finance, 61(2), 655-687. http://dx.doi.org/10.1111/j.1540-6261.2006.00851.x

Cornelli, F., Goldreich, D., \& Ljungqvist, A. (2006). Investor sentiment and pre-IPO markets. The Journal of $\quad$ Finance, 61(3), 1187-1216. http://dx.doi.org/10.1111/j.1540-6261.2006.00870.x

Cremers, K. J. M., \& Nair, V. B. (2005). Governance mechanisms and equity prices. The Journal of Finance, 60(6), 2859-2894. http://dx.doi.org/10.1111/j.1540-6261.2005.00819.x

De Long, J. B., Shleifer, A., Summers, L. H., \& Waldmann, R. J. (1990). Noise trader risk in financial markets. Journal of Political Economy, 98(4), 703-738. http://dx.doi.org/10.1086/261703

Dechow, P. M., Sloan, R. G., \& Sweeney, A. P. (1996). Causes and consequences of earnings manipulation: An analysis of firms subject to enforcement actions by the SEC. Contemporary Accounting Research, 13(1), 1-36. http://dx.doi.org/10.1111/j.1911-3846.1996.tb00489.x

Dong, M., Hirshleifer, D., \& Teoh, S. H. (2007). Stock market misvaluation and corporate investment. MPRA Paper. University Library of Munich, Germany.

Dorn, D. (2009). Does sentiment drive the retail demand for IPOs? Journal of Financial and Quantitative Analysis, 44(01), 85-108. doi:10.1017/S0022109009090024 
Fama, E. F. (1980). Agency problems and the theory of the firm. Journal of Political Economy, 88(2), 288-307. http://dx.doi.org/10.1086/260866

Firstenberg, P. B., \& Malkiel, B. G. (1980). Why corporate boards need independent directors. Management Review, 69(4), 26-38.

Fischer, S., \& Merton, R. C. (1984). Macroeconomics and finance: The role of the stock market. Carnegie-Rochester Conference Series on Public Policy, 21(0), 57-108. http://dx.doi.org/10.1016/0167-2231(84)90005-8

Gilchrist, S., Himmelberg, C. P., \& Huberman, G. (2005). Do stock price bubbles influence corporate investment? Journal of Monetary Economics, 52(4), 805-827. http://dx.doi.org/10.1016/j.jmoneco.2005.03.003

Giroud, X., \& Mueller, H. M. (2010). Does corporate governance matter in competitive industries? Journal of Financial Economics, 95(3), 312-331. http://dx.doi.org/10.1016/j.jfineco.2009.10.008

Grundy, B. D., \& Li, H. (2010). Investor sentiment, executive compensation, and corporate investment. Journal of Banking \& Finance, 34(10), 2439-2449. http://dx.doi.org/10.1016/j.jbankfin.2010.03.020

Harford, J. (1999). Corporate cash reserves and acquisitions. The Journal of Finance, 54(6), 1969-1997. http://dx.doi.org/10.1111/0022-1082.00179

Harford, J., Mansi, S. A., \& Maxwell, W. F. (2008). Corporate governance and firm cash holdings in the US. Journal of Financial Economics, 87(3), 535-555. http://dx.doi.org/10.1016/j.jfineco.2007.04.002

Huang, H. H., Huang, I. H., \& Chang, C. H. (2011). Corporate performance after substantial capital expenditure: The role of growth opportunity and corporate governance. NTU management Review, 22(1), 297-325. http://dx.doi.org/10.6226/NTURM2011.22.1.297

Jensen, M. C. (1986). Agency costs of free cash flow, corporate finance, and takeovers. The American Economic Review, 76(2), 323-329. http://dx.doi.org/10.2139/ssrn.99580

Jensen, M. C. (1993). The modern industrial revolution, exit, and the failure of internal control systems. The Journal of Finance, 48(3), 831-880. http://dx.doi.org/10.1111/j.1540-6261.1993.tb04022.x

Jensen, M. C., \& Meckling, W. H. (1976). Theory of the firm: Managerial behavior, agency costs and ownership structure. Journal of Financial Economics, 3(4), 305-360. http://dx.doi.org/10.1016/0304-405X(76)90026-X

Kao, L., Chiou, J.-R., \& Chen, A. (2004). The agency problems, firm performance and monitoring mechanisms: The evidence from collateralised shares in Taiwan. Corporate Governance: An International Review, 12(3), 389-402. http://dx.doi.org/10.1111/j.1467-8683.2004.00380.x

Kau, J. B., Linck, J. S., \& Rubin, P. H. (2008). Do managers listen to the market? Journal of 
Corporate Finance, 14(4), 347-362. http://dx.doi.org/10.1016/j.jcorpfin.2008.03.002

Keynes, J. M. (1936). The general theory of employment, interest and money. London: McMillan.

La Porta, R., Lopez-De-Silanes, F., Shleifer, A., \& Vishny, R. (2002). Investor protection and corporate valuation. The Journal of Finance, 57(3), 1147-1170. http://dx.doi.org/10.1111/1540-6261.00457

Lemmon, M., \& Portniaguina, E. (2006). Consumer confidence and asset prices: Some empirical evidence. The Review of Financial Studies, 19(4), 1499-1529. http://dx.doi.org/10.1093/rfs/hhj038

Lucas, D. J., \& McDonald, R. L. (1990). Equity issues and stock price dynamics. The Journal of Finance, 45(4), 1019-1043. http://dx.doi.org/10.1111/j.1540-6261.1990.tb02425.x

Masulis, R. W., Wang, C., \& Xie, F. (2007). Corporate governance and acquirer returns. The Journal of Finance, 62(4), 1851-1889. http://dx.doi.org/10.1111/j.1540-6261.2007.01259.x

McConnell, J. J., \& Muscarella, C. J. (1985). Corporate capital expenditure decisions and the market value of the firm. Journal of Financial Economics, 14(3), 399-422. http://dx.doi.org/10.1016/0304-405X(85)90006-6

Morck, R., Shleifer, A., Vishny, R. W., Shapiro, M., \& Poterba, J. M. (1990). The stock market and investment: Is the market a sideshow? Brookings Papers on Economic Activity, 1990(2), 157-215. http://dx.doi.org/10.2307/2534506

Opler, T., Pinkowitz, L., Stulz, R., \& Williamson, R. (1999). The determinants and implications of corporate cash holdings. Journal of Financial Economics, 52(1), 3-46. http://dx.doi.org/10.1016/S0304-405X(99)00003-3

Opler, T., Pinkowitz, L., Stulz, R., \& Williamson, R. (2001). Corporate cash holdings. Journal of Applied Corporate Finance, 14(1), 55-67. http://dx.doi.org/10.1111/j.1745-6622.2001.tb00320.x

Polk, C., \& Sapienza, P. (2009). The stock market and corporate investment: A test of catering theory. The Review of Financial Studies, 22(1), 187-217. http://dx.doi.org/10.1093/rfs/hhn030

Qiu, L., \& Welch, I. (2004). Investor sentiment measures. National Bureau of Economic Research.

Richardson, S. (2006). Over-investment of free cash flow. Review of Accounting Studies, 11(2-3), 159-189. http://dx.doi.org/10.1007/s11142-006-9012-1

Shleifer, A., \& Vishny, R. W. (1997). The limits of arbitrage. The Journal of Finance, 52(1), 35-55. http://dx.doi.org/10.1111/j.1540-6261.1997.tb03807.x

Sivaramakrishnan, S., \& Yu, S. C. (2008). On the association between corporate governance and earnings quality. Paper presented at the AAA 2008 Financial Accounting and Reporting 
Section (FARS).

Sloan, R. G. (1996). Do stock prices fully reflect information in accruals and cash flows about future earnings? The Accounting Review, 71(3), 289. Retrieved from http://www.jstor.org/stable/248290

Stein, J. C. (1996). Rational capital budgeting in an irrational world. Journal of Business, 69(4), 429-455. Retrieved from http://www.jstor.org/stable/2353403

Strong, J. S., \& Meyer, J. R. (1990). Sustaining investment, discretionary investment, and valuation: A residual funds study of the paper industry. In e. R. Glenn Hubbard (Ed.), Asymmetric Information, Corporate Finance, and Investment (pp. 127-148): University of Chicago Press. Retrieved from http://EconPapers.repec.org/RePEc:nbr:nberch:11470

Teoh, S. H., Welch, I., \& Wong, T. J. (1998). Earnings management and the long-run market performance of initial public offerings. The Journal of Finance, 53(6), 1935-1974. http://dx.doi.org/10.1111/0022-1082.00079

Trueman, B. (1986). The relationship between the level of capital expenditures and firm value. The Journal of Financial and Quantitative Analysis, 21(2), 115-129. http://dx.doi.org/10.2307/2330732

Weisbach, M. S. (1988). Outside directors and CEO turnover. Journal of Financial Economics, 20(0), 431-460. http://dx.doi.org/10.1016/0304-405X(88)90053-0

Yeh, Y. H. (1999). Family groupings, core business and return interaction: Taiwan and Hong Kong stock markets. Management Review, 18(2), 59-86.

Yeh, Y. H., Lee, T. S., \& Woidtke, T. (2001). Family control and corporate governance: Evidence from Taiwan. International Review of Finance, 2(1-2), 21-48. http://dx.doi.org/10.1111/1468-2443.00014

Yermack, D. (1996). Higher market valuation of companies with a small board of directors. $\begin{array}{llll}\text { Journal of Financial } & \text { Economics, } & \text { 40(2), }\end{array}$ http://dx.doi.org/10.1016/0304-405X(95)00844-5

Young, C. S., \& Wu, S. J. (2009). The determinants and effects on earnings informativeness of asset impairments: The role of corporate governance. International Journal of Accounting Studies, 48, 67-114. 